\title{
Going with the consumer towards the social Web environment: a review of extant knowledge
}

\author{
Inma Rodríguez-Ardura \\ Internet Interdisciplinary Institute, \\ Open University of Catalonia (Universitat Oberta de Catalunya or UOC)
}

Francisco J. Martínez-López

Marketing Department,

Universidad de Granada

\section{Paula Luna}

Department of Financial Economy and Operations Research, University of Seville

Author Posting. (c) 'Copyright Holder', 2010.

This is the author's version of the work. It is posted here for personal use, not for redistribution.

The definitive version was published in International Journal of Electronic

Marketing and Retailing, Volume 3 Issue 3, 2010.

\begin{abstract}
The social Web environment cannot be explained without taking into account the use made by consumers of the web technologies in the field of ecommerce. Starting with a systematic background of the growing body of research on marketing and consumer behaviour on the Web; this article presents a critical review of the main contributions on this theme, integrating also the research field of consumer behaviour in the social Web environment. It concludes with some managerial guidelines for successful use of the social Web in the commercial activities and in the establishment of fruitful relationships between the consumers and the brand.
\end{abstract}

Keywords: Consumer behaviour; social Web; Web; review

Biographical notes: Inma Rodríguez-Ardura is an Associate Professor of Marketing in Economic and Business Studies and a Researcher of the Internet Interdisciplinary Institute at the Open University of Catalonia (Universitat Oberta de Catalunya or UOC), Spain. She obtained her PhD in Economic and Business Sciences at the University of Barcelona. Her research interests include e-commerce, consumer behaviour on the Internet and marketing e-learning interface. She is the author of several books and articles on these areas.

Francisco J. Martínez-López, MSc in Marketing, European $\mathrm{PhD}$ in Business Administration, is an Associate Professor in Marketing at the University of Granada (Spain) and Assistant Professor in Marketing at the Open University of Catalonia (Spain). Among his main areas of interest are consumer behaviour on the Internet, e-marketing, marketing channels and KDD methodologies for marketing. 
Paula Luna, $\mathrm{PhD}$ in Economic and Business Sciences, is a Professor of the University of Seville, Spain and lectures in Information Systems. She has been a guest lecturer and researcher at several universities (Lyon II, France; Vladivostok, Russia; Santa Fé, Argentina; etc.) and is Director of the ICT research group of the company Gitice. She has taken part in several business research projects at domestic and European levels. She has also worked in a consultancy and training capacity for a number of national and multinational companies.

\section{Introduction}

From the consumer's point of view, the Web offers numerous advantages. On the one hand, the Web allows consumers to play a more active role in communication processes, facilitating, like no other medium until now, their ability to obtain and exchange information and opinions. Furthermore, the emergence of the tools and services offered by the socalled Web 2.0 has provided them with even greater possibilities for participation and exchange by way of social communities and networks. On the other hand, online consumers benefit from a greater degree of personalization in the communications and services which are presented to them. The Web opens the door for consumers to a wide variety of products, much greater than those offered by local establishments; it facilitates product comparison; and it offers access to a great amount of information regarding items on sale, etc. These characteristics have made the Web, and especially this new generation of Web-based social networks, a motor for change in the relationships between businesses and their brands and the consumer.

The contributions made by marketing and by, in particular, the discipline of consumer behaviour to the study of the Web are evident in the development of studies that aid the understanding of people's activities with respect to their experiences as consumers in this new context. In fact, in order to provide a structured vision of these contributions, this article focuses primarily on bringing together a wide and synthetic view of the diversity of research interests, fields and variables which characterize the study of consumer behaviour in the Web. It also pays special attention to the studies focused on the possibilities derived from the emergence of the Web 2.0 and the applications of the social Web, which allow consumers to benefit from a collective intelligence, to acquire greater control over information, and to participate in new ways of relating to the brand. The consideration of this particular topic, along with the others, aims to offer an integrative and modern view of the main topics of research characterizing the field of consumer behaviour on the Internet.

Finally, this article proposes several managerial guidelines which are based on the literature we have examined, especially with respect to the new Social Web framework; e.g.: consumers' empowerment, the change 
in the conception of the consumer's relationship with the brand, the reconfiguration of the focus of the relationships and new ways in which to propose the generation of online value, among others.

\section{Theoretical background: the interface between the Web and consumer behaviour}

Early research related to Web-based consumer behaviour focused on obtaining user profiles and on the segmentation of consumers who used the Web. However, as use of the Web as a marketing channel increased, resulting in its wider use as a purchasing medium, subsequent research became centred on a plethora of questions directly related to consumer behaviour. In a study by Kımıloğlu (2004), an extensive review of the diverse research streams focused on marketing and the Internet can be found. In particular, said author highlights four main structural lines for the consumer behaviour discipline in electronic markets: major characteristics related to the online consumer, the study of the factors influencing the degree of the consumer's involvement in purchasing behaviours; the analysis of the purchasing process on the Web; consumer satisfaction and loyalty on the Web; and models and theories related to the electronic markets.

\subsection{Profile of Web users}

One of the initial lines of investigation that characterized the studies of the environment defined by the interface between the Web and consumer behaviour saw a number of studies centred on identifying typical consumer profiles. These profiles were of Web users, in particular of those users who made a practice of online purchasing. Researchers following this line of investigation have focused on analyzing the influence socioeconomic, demographic and psychographic characteristics exert on the users and attitude towards and use of the Web, as well as analyzing users' practices and attitudes towards electronic commerce, purchase levels, etc. It is worth noting the following groups of investigations which centre on each one of those profile characteristics.

- Age (Chang and Samuel, 2004; Dholakia and Uusitalo, 2002; Floh and Treiblmaier, 2006; Forsythe and Shi, 2003; Hoffman et al., 1996; Teo, 2001; Trocchia and Janda, 2000; Vuori and Holmlund-Rytkönen, 2005; Wu, 2003).

- Gender (Bellman et al., 1999; Floh and Treiblmaier, 2006; Gefen and Straub, 1997; King, 2001; Sánchez-Franco, 2006; Teo, 2001; Teo and Lim, 1997; Venkatesh and Morris, 2000; Whitly, 1997; Wu, 2003). 
- Marital status (Hoffman et al., 1996; Karjaluoto et al., 2002; Katz et al., 2001).

- Employment/Occupation type (Teo, 1998; Wu, 2003).

- Experience in using the Web and computers (Bhatnagar et al., 2000; Balabanis and Vassileiou, 1999; Hammond et al., 1998; Helander and Khalid, 2000; Hoffman et al., 1996; Liao and Cheung, 2001; MartínezLópez et al., 2005; Montoya-Weiss et al., 2003; Novak et al., 2000).

- Level of income (Chang and Samuel, 2004; Forsythe and Shi, 2003; $\mathrm{Wu}, 2003)$.

- Level of studies (Hoffman et al., 1996; Katz et al., 2001; Teo, 2001; $\mathrm{Wu}, 2003)$.

There have also been a great number of studies interested in obtaining user profiles, with the aim of improving the segmentation of the electronic markets. Looking at early studies, one can appreciate the tendency to establish parallels between the profiles found for users of distance shopping channels and those of the Web (Burke, 1997). The typical Web user was a young person, single, male, with a relatively high level of studies - usually university - and a high income (Donthu and Garcia, 1999; Li et al., 1999). Given that the rate of penetration by the Web in homes was still low, the articles which analyzed the differences between users and non-users were habitual (Hoffman et al., 1996; Hoffman and Novak, 1997). Nevertheless, as use of the Web has spread among the world's population, the differences in terms of socioeconomic and demographic structures have lessened, approximating the profiles for audiences of mass communication media. In light of this circumstance, the most recent studies have shifted their attention to the profiles of users who make more intensive use of the Web. Curiously, recent studies have concluded that this segment of users, in their composition, looks a lot like the first adopters of the Web, a decade ago (Assael, 2005).

\subsection{Characteristics of buyers on the Web}

In addition to the characteristics described for user profiles in general, studies concerned with an analysis of the profile of buyers on the Web highlight the following: a greater propensity for risk, a lifestyle marked by pressure and strongly conditioned by limiting time constraints, greater experience in general with distance shopping, and in particular with purchasing on the Web, above average levels of trust in the Web as a means of making purchases, and higher education levels (Bellman et al., 1999; Dholakia and Uusitalo, 2002; Donthu and Garcia, 1999; Kau et al., 2003; Li et al., 1999; Swinyard and Smith, 2003).

\subsection{Influencing factors in making online purchases}


The identification and analysis of the factors involved in explaining the consumer's predisposition/intention to buy on the Web -as well as explaining the actual purchase- figure prominently in much of the latest research. Apart from the models used to this end, in which the variable of intention to buy is usually integrated as a terminal element, several different variables have been deployed in an effort to understand what it is that influences purchases on the Web; some of these variables are determined to exert a more direct or immediate influence, while others are seen to interact in an indirect fashion with the purchase variable. We refer specifically to the following:

1) Perceived safety in the transaction (Attaran and Vanlaar, 1999; Iyengar, 2004; Miyazaki and Fernandez, 2001; Phillips, 2002; Udo, 2001).

2) Quality of service on the Web (Liu and Arnett, 2000; Long and McMellon, 2004; Surjadjaja et al., 2003; Trocchia and Janda; 2003; Yang and Jun, 2002; Yang et al., 2003; Zeithaml et al., 2002).

3) Questions related to product price or service acquired (Garbarino and Lee, 2003; Grewal et al., 2003; Jiang, 2002; Miyazaki, 2003).

4) Invasion of privacy risks (Aljifri et al., 2003; Ashrafi and Kuilboer, 2005; Attaran and Vanlaar, 1999; Gritzalis, 2004; Hoffman et al., 1999a; Kruck et al., 2002; Larson et al., 2003; Martínez-López et al., 2005; Miyazaki and Fernandez, 2001; Nakra, 2001; Phillips, 2002; Udo, 2001; Wang et al., 1998).

5) Beliefs and attitude towards the Web (Alreck and Settle, 2002; Bhatnagar et al., 2000; George, 2002; Goldsmith and Bridges, 2000; Helander and Khalid, 2000; Kim et al., 2003; Sorce et al., 2005; Shim et al., 2001; Vellido et al., 2000; Yoh et al., 2003).

6) Purchasing confidence in the Web as a purchasing channel (Aljifri et al., 2003; Jarvenpaa and Todd, 1997; Grabner-Kraeuter, 2002; Hoffman et al., 1996; Hoffman et al., 1999b; Lee and Turban, 2001; Limayem et al., 2000; Lynch et al., 2001; Martínez-López et al., 2005; McKnight and Chervany, 2001; McKnight et al., 2002; Shankar et al., 2002; Urban et al., 2000; Vijayasarathy and Jones, 2000).

7) Trust in the online vendor (Castelfranchi and Tan, 2002; Chen and Dhillon, 2003; Ha, 2004; Jarvenpaa et al., 1999 \& 2000; Koehn, 2003; Lee and Turban, 2001; Tan and Thoen, 2000; Wakefield and Whitten, 2006).

8) The consumer's experience in the use of the Web to obtain information and to make purchases (Balabanis and Vassileiou, 1999; Helander and Khalid, 2000; Hoffman et al., 1996; Hoffman et al., 1999b; Liao and Cheung, 2001; Maignan and Lukas, 1997; MontoyaWeiss et al., 2003; Novak et al., 2000). 
9) The hedonistic value associated with Web purchases (Childers et al., 2001; Mathwick et al., 2001 and 2002; Martínez-López et al., 2006; Wolfinbarger and Gilly, 2001).

10) The consumer's perceived control over the process of navigating the Web and over electronic transactions, and, in general, the degree of facility perceived regarding the process of electronic exchanges with businesses on the Web (Hoffman and Novak, 1996; George, 2004; Goldsmith and Goldsmith, 2002; Johnson et al., 2003; O'Cass and Fenech, 2003; Pavlou, 2003; Shih and Fang, 2004; Shim et al., 2001).

11) Situational factors that can moderate the relationship among variables considered previously and purchasing on the Web. These act, for example, as elements which increase the probability that the consumer will complete an electronic transaction. Some of the more relevant factors are: time constraints, lack of mobility, geographical distances, the need for specific products or services, and the attractiveness of certain shopping alternatives (Avery, 1996; Perea y Monsuwé et al., 2004; Wolfinbarger and Gilly, 2001).

\subsection{Analysis of the purchasing process on the Web}

Another important research stream, though one followed less intensely, is the analysis of the purchasing process on the Web. Among the questions examined are:

a) The identification of the principal factors that discourage and inhibit consumers when purchasing on the Web. The following are some of the factors that have been observed (Betts, 2001; Mayer, 2002): difficulties in sending the goods to be acquired, elevated transport costs, lack of associated information -with respect as much to the goods to be acquired as to the electronic transaction to be realized-, the diversity of risks associated with the operation and which are a consequence of a generalized fear regarding purchases made through the Web, etc.

b) The identification of the reasons the shopping cart is abandoned after an item is selected. The following enumeration serves to highlight the most recurrent reasons that have been observed, (Donthu, 2001; Plant et al., 2003; Scullin et al., 2004; Van Iwaarden et al., 2003): unsatisfactory comparison with parallel purchasing processes which take place on the Web, change of opinion, product costs which are too high, a purchasing process which is too complicated -which generates a feeling of desperation and frustration in the consumer-, the request of too much personal information, confusing closing process, etc.

c) Why there is no correspondence between the number of more or less regular purchasers and the number of visits. 
d) Why a consumer who visits a particular commercial website finally decides to go ahead with an electronic transaction (Swaminathan, Lepkowska-White and Rao, 1999; etc.).

\subsection{Satisfaction and loyalty on the Web}

The study of a consumer's satisfaction with a Web purchase, as well as users' loyalty and fidelity to virtual establishments with regards to the purchase (what is typically referred to as e-loyalty), have aroused researchers' interest in recent times. These concepts are closely related, given the necessary sequence of appearance the two must follow; that is, satisfaction is a step which precedes and shapes the development of loyalty towards something (Oliver, 1999). Thus, consumer satisfaction must be attended to if the establishment of a long term relationship with customers is desired (Patterson et al., 1997). The relationship between these concepts has materialized in many studies that have taken consumer behaviour in physical establishments as their framework, although in studies of consumer behaviour on the Web it is necessary to consider other factors which moderate this relationship (Bigné et al., 2005).

One of the principal conclusions which can be drawn from studies centred on consumer e-satisfaction is that the adequate identification and understanding of the principal satisfaction determinants is crucial to the success of every business on the Web (Mckinney et al., 2002). In addition, and in accordance with the conceptual model proposed by Schaupp and Bélanger (2005), it is important to emphasize the following factors, some of which occur more frequently than others, as principle antecedents of esatisfaction:

- Technological factors that ensure website functionality, such as security, privacy and usability/site design.

- Factors that influence consumer perceptions during and after the purchase, such as convenience, confidence in the virtual establishment and, finally, the delivery of the purchased items.

- Factors associated with the quality of the product and service being offered, such as the presentation of the selection of products (merchandising), product value and the adaptation of the same to the concrete needs of the individual.

The concept of e-loyalty, in line with the postulates of similar studies focused on brand loyalty in the physical markets (for example: Day, 1969; Jacoby, 1971; Jacoby and Chestnut, 1978), is understood as something more than just the consumer's repeated tendency to buy in a specific web establishment, since this behaviour could be the consequence of other spurious factors; for example, the web establishment may be the only one which has a certain product, it is impossible to access the offering at other 
establishments, etc. Thus, it is not the mere repetition of purchases that defines a consumer's loyalty to a web space, but, rather, it his or her preference and positive attitude towards that site over all others. In this way, the observed behaviour would be consistent with the preferences and attitudes on the part of the consumer towards the website. The fact that businesses on the Web count on a tranche of loyal customers has led academics to take an interest in discovering the factors that determine loyalty (see, for example: Srinivassan et al., 2002).

\subsection{Trust in purchasing through the Web}

Another important research line is that of aspects related to trust in purchasing on the Web. Various studies (e.g.: Butler and Peppard, 1998; Reynolds, 2000; Rowley, 2000) have highlighted the fact that, due to the special characteristics of Web transactions, companies with a Web presence feel the need to generate confidence and brand image in such a way that consumers show a greater predisposition towards carrying out purchasing processes on their sites. So, a lack of consumer trust in this medium is one of the main factors that inhibit electronic transactions (Hoffman et al., 1999b). Furthermore, it is to be expected that consumers will not carry out a Web transaction unless the perceived level of trust exceeds a minimum level of acceptability to the consumer (Castelfranchi and Tan, 2002; Tan and Thoen, 2000). Besides, different merchandise categories (Newholm et al., 2004) and different consumers (Bart et al., 2005) require the development of different levels or types of trust.

Specifically, Urban et al. (2000) define trust in the Web as a channel for purchases, in terms of consumers' opinions regarding safety, evident transparency in the transaction entered into with companies on the Web, and the companies' commitment to respect what has been transacted with the consumer. On the other hand, Lee and Turban (2001) indicate that trust in purchases made on the Web is a two-dimensional concept articulated by confidence in the support/infrastructure of the market and in the companies that operate within this support, i.e.: (1) trust in the Web as a medium of purchase; and (2) trust in the companies that operate on the Web. Likewise, McKnight et al. (2002) begin with a holistic philosophy to give shape to what they term the "web trust model", a model which contemplates various facets: consumer predisposition towards trust in the generic sense, trust in the Web as a medium for purchase and, particularly, trust in the website of a specific company.

2.7 Adoption of classic theories and models to explain consumer behaviour on the Web 
Another noteworthy line of investigation refers to the adaptation of classical theories and models relating to consumer behaviour-specifically attitude models - to explain the adoption of the Web and electronic commerce. The contributions to this area of study are many and varied, but they can be generally classified in the following manner (Kımıloğlu, 2004; Rodríguez del Bosque and Herrero, 2005):

a) Adaptation of the theory of reasoned action (Fishbein and Ajzen, 1975; Ajzen and Fishbein, 1980) and planned behaviour (Schifter and Ajzen, 1985). See, for example, George (2004).

b) Adaptation of the Technology Acceptance Model (TAM) proposed by Davis (1989). See, for example, Chen and Tan (2004).

c) Adaptation of the adoption-diffusion of innovations model (Gatignon and Robertson, 1985). See, for example, Herrero and Rodríguez del Bosque (2008).

d) Application of the decomposed theory of planned behaviour (Taylor and Todd, 1995). See, for example, Shih and Fang (2004).

e) Application of the flow state concept (Csikszentmihalyi, 1975) to explain the adoption and use of commercial electronic systems. We highlight the seminal work of Hoffman and Novak (1996), whose conceptual model subsequently was validated empirically in Novak et al. (2000).

f) Integration of the TAM model with the flow condition to explain Web surfing and the use of the Web and of individual sites. See, for example: Sánchez-Franco and Roldán (2005) and Sánchez-Franco (2006).

\section{Consumer engagement with the social Web: the marketing connection}

In the last few years, after the emergence of the so-called Web 2.0 and the applications of social networking, a new wave of marketing discipline studies has surged forth, concretely in the field of consumer behaviour. Unlike traditional web sites, designed primarily for the consumer to be exposed to its contents, these new resources constitute real environments for encounters, collaboration and interaction between users, in a manner which, furthermore, is free, open and decentralized. The tools, services and social networking software gracing these environments (such as blogs, wikis, folksonomies, syndication channels, spaces and profiles, etc.), stimulate altruistic participation, on the part of the users, in favour of the community: searching for, elaborating and sharing content, transmitting opinions, labelling or classifying, etc. All of this allows users to benefit 
from a collective intelligence and to acquire a greater control over information.

These new possibilities offered by the Social Web, along with the processing systems used to manage great masses of consumer data, make advanced forms of interaction and relationships between consumers possible; i.e. the consumers' greater participation in value generation, a greater adaptation of the content and services to fit individual needs, an elevated interaction that brings consumers closer to others who are also more closely associated with the brand, etc. Curiously, these new keys that characterize online exchanges are in sync with the thrust of recent proposals in marketing, such as, for example, new service-dominant logic (Vargo and Lusch, 2004) and Customer Relationship Marketing, or CRM (Boulding et al., 2005). Key questions underlying the modern spirit of marketing, such as customer satisfaction through value delivery, relationship orientation, intelligent use of technological systems and interfunctional business processes to obtain and communicate knowledge relating to the customer, personalization, etc., come together in the form of a marketing logic centred upon the synergetic interaction of tangible and intangible resources in the co-creation of value (Vargo and Lusch, 2004). In this context, the consumer becomes a co-creator of value (Payne et al., 2008; Prahalad and Ramaswamy, 2004; Vargo and Lusch, 2004), and emphasis is put on the development of customer-supplier relationships through interaction and dialogue (Payne et al., 2008).

In fact, the recent and still relatively few studies carried out on consumer behaviour in the new environment defined by Social Web applications can be grouped according to these subjects relating to changes in marketing, allowing us to distinguish up to four incipient lines of investigation: (1) the increase of consumer empowerment, due to the role assigned by recent Web-based applications to individuals, in general, and consumers, in particular, in their relations with firms and Web users; (2) the new routes for co-creation of value and for participation/collaboration on the part of the consumer in processes of innovation and in the generation of content; (3) the impact of personalization practices tied to CRM programs and to the new forms of interaction; and, finally, (4) the relationship with the brand in virtual communities. Also, we can consider a fifth group of studies focused on analyzing consumer behaviour in concrete applications on the social Web.

\subsection{Consumer empowerment on the Web}

First of all, we wish to call attention to a research stream which is beginning to gain importance and which considers the Web (and especially social Web technologies) to be an instrument with which to 
empower consumers (e.g., Harrison et al., 2006; Pires et al., 2006; Pitt et al., 2002; Rezabakhsh et al., 2006; Rodríguez-Ardura and MartínezLópez, 2008). Typically, this question is tackled by considering and analyzing the different sources of empowerment on the Web (Rezabakhsh et al., 2006; Rodríguez-Ardura and Martínez-López, 2008). Frequently, this class of studies tends to derive from a notable current of opinion which has taken shape following the pioneering work of Alba et al. (1997), Bakos (1997) and Brynjolfsson and Smith, (2000), and which has laid the foundations for greater power on the part of online consumers, thanks to greater informative transparency regarding electronic exchanges. However, the consumer behaviour discipline takes additional sources of empowerment into consideration, such as the online consumers' increased capacity to intervene directly in the shaping of a value proposition adapted to their individual needs (Pires et al., 2006), as well as their greater capacity to "sanction" firms (Rezabakhsh et al., 2006).

Nonetheless, the evidence obtained reveals different behaviour patterns as far as empowerment is concerned. While a relevant segment of online consumers are prone to increase their levels of empowerment, there are others who use the Web to enhance their empowerment. This second group of consumers are better informed and more active. Some of their distinguishing characteristics are: an use of advanced tools to make the most efficient and effective searches for products (Deck and Wilson, 2006; Sen et al., 2006); a defence against intrusive or discriminatory marketing initiatives (Acquisti and Varian, 2005); a willingness to propagate their opinions and recommendations among many other consumers (Carl, 2006); a higher predisposition to participate in the design of a value proposition that satisfies their preferences (Kamali and Loker, 2002).

3.2 Consumer participation in value creation: from co-creation to collective innovation through the Web

The emergence of the Web is boosting the consumer's involvement in value co-creation processes to a great degree (Bonsu and Darmody, 2008; Hars and Qu 2002; Jeppesen and Frederiksen, 2006; Oreg and Nov, 2008; Piller et al., 2005; Pitta and Fowler, 2005; Rowley et al., 2007, Xu et al., 2009 , etc.), as these processes allow the consumer to participate much more actively in the development and consumption of products (Bendapudi and Leone 2003). For example, Nambisan (2002) has considered the varied forms in which web environments emphasize different consumer roles in innovation and value creation (in the generation of ideas, in product design and development, in product testing, and in product support services). Nambisan and Baron (2007) highlight the 
importance of the interactions of consumers on the Web as a source of value. On the one hand, the consumers' perceptions of the benefits to be derived from their interaction condition their future participation in cocreation processes. And on the other hand, the interactions generate changes in their affective states which, at the same time, help shape their attitude towards the business.

In a similar manner, the consumer engagement with co-creation processes has recently experienced new advances thanks to the resources and tools that come with the Web 2.0 (e.g.: wikis, folksonimies, web blogging, virtual worlds, etc.) and thanks to collaborative models of the social Web (such as those that are the result of the open-source movement). This wave of new resources and contexts has given meaning to new learning network paradigms developed around the idea of open knowledge (Albors et al., 2008), as well as to consumers' awareness of being complete collective creative forces unto themselves (Benkler, 2006; Lévy, 1997; Rheingold, 2002). In an effort to elaborate a framework based on the phenomenon of collective innovation through the Web, Kozinets et al. (2008) distinguish the defining dimensions of this class of collectives: oriented towards the attainment of objectives relative to the production of innovation (telo-specific orientation vs. communo-ludic orientation), and the concentration of innovative contribution at the heart of the collective.

Within innovation environments, certain elements intervene which allow for the auto-generation of content and the aggregation of commentaries and ideas contributed by individual consumers, and also feed back into business through word-of-mouth marketing campaigns (Kozinets et al., 2008). Indeed, the use of this last type of initiative and its impact on consumers has been approached by various investigations (see, e.g., Brown et al., 2007; De Bruyn and Lilien, 2008; Dwyer, 2007).

\subsection{Web personalization}

The third notable line of investigation draws together those studies dedicated to the analysis and promotion of theories relating to the personalization processes carried out via web-based interaction (Miceli et al., 2007; Randall et al., 2005; Vesanen and Raulas, 2006; Wind and Rangaswamy, 2001; among others), as well as to modelling consumer behaviour on personalization processes (e.g. Ansari and Mela, 2003). The focus is on one characteristic which is particular to these processes, given that, thanks to these Web-based technologies -especially the new generation of Social Web applications- and to the support offered by CRM solutions -which facilitate an interaction better suited to consumers as well as making it possible to obtain relevant knowledge- it is possible to deploy advanced forms of personalization. These advanced forms bring 
great flexibility to operations -already enabled by mass customization (Pine, 1993)- as well as to interaction and communications -already initiated by the one-to-one marketing solutions (Peppers and Rogers, 1993)-, allowing not only for the customization of the products/services but in fact for the whole consumption experience (Wind and Rangaswamy, 2001).

This research stream has called attention to some critical aspects of the impact personalization initiatives have had on the consumers: consumers may perceive the initiatives as being excessively complex (Dellaert and Stremersch, 2005) or, they may feel frustrated if they do not have or exercise sufficient knowledge, expertise and involvement (Bendapudi and Leone, 2003). For this reason, recent studies such as that carried out by Miceli et al. (2007) propose that Web personalization should be developed within the framework of CRM programs which adapt the degree of personalization to each consumer, and so are able to consider aspects such as their preferences with respect to content or interaction.

\subsection{Virtual communities and relationships with the brand}

Among the distinct lines of investigation linked to Social Web environments, the line which chooses virtual communities as the focus of study has attracted, up to now, the greatest interest. This is due, in great part, to the fact that virtual communities were being studied even before the advent of the latest generation of collaborative applications. Furthermore, the important implications virtual communities hold for the world of marketing and commerce are leading to the elaboration of ever more empirical investigations (e.g., Blanchard, 2008; Dholakia et al. 2004; Dou and Krishnamurthy, 2007; Jang et al., 2008; Jepsen et al., 2006; Koh and Kim, 2003; Lin, 2007).

A number of investigations have set out to study consumers' motivations in participating in virtual communities (Ridings and Gefen, 2004; Wasko and Faraj, 2000) or have examined the nature and function of the social influence exercised by virtual communities on its members (see, e.g. Bagozzi and Dholakia, 2002; Dholakia et al., 2004; Kim et al., 2008; Postmes et al., 2000), apart from other determinants relating to participation in these relationship networks (Bishop, 2007; Lin, 2007; Schoberth et al., 2006).

The classification and analysis of virtual communities constitutes another topic of study open to investigation. The diverse classification criteria that have been proposed include: the activities taking place at the heart of the community and the objectives to which they respond (Hagel and Armstrong, 1997), community size and the off-line relationships between members (Dholakia et al. 2004), the establishment and 
orientation of the relationships (Porter, 2004), etc. A distinction which is utilized in a number of investigations (Blanchard and Horan, 1998; Koh and Kim, 2003; among others) centres on the difference between communities of interest and communities of practice (Wenger, 1998). Kozinets (1999), in turn, proposes a classification on the basis of the dimensions group focus (information exchange vs. social interaction) and social structure.

In any case, virtual consumption communities and, in particular, those created around a commercial brand (Muñiz and O'Guinn, 2001), coherently in line with their implications for commerce (see, as e.g.: Flavián and Guinalíu, 2005; McWilliam, 2000), attract growing attention. Brand communities are promoted and cultivated by businesses within the framework of CRM programs (Winer, 2001), with the aim of offering social consumer experiences centred on the benefits of the brand (McAlexander et al., 2002). With all this, there is a lack of empirical studies on the behaviour of consumers who are integrated within online brand communitites, given that the greater part of the studies carried out are of a conceptual nature (e.g. Macaulay et al., 2007) or do not offer results that can be generalized (Andersen, 2005; Cova and Pace, 2006; Sicilia and Palazon, 2008; Szmigin and Reppel, 2004; among others).

Muñiz and O'Guinn (2001) turn to three constructs to define brand communities: consciousness of kind, presence of shared rituals and traditions, and a sense of moral obligation towards the group. Also, they have identified varied characteristics and behaviours of the online brand communities:

- They are defined by their opposition to other brands and communities (Muñiz and Hamer, 2001; Muñiz and O'Guinn, 2001; Thompson and Sinha, 2008).

- They act as a source of information, learning and assistance in the use of the product (Muñiz and O'Guinn, 2001).

- They offer social recognition to the consumer (Cova and Pace, 2006).

- They question the legitimacy of those consumers (as members of the community) whom they consider to be opportunistic or who acquire the product for the "wrong reasons" (Muñiz and O'Guinn, 2001, p. 419).

- At times, they attempt to maintain a community which is reduced in size and even marginal (O'Guinn and Muñiz, 2005).

- Their existence can be prolonged even when it has been abandoned by the brand and the company (Muñiz and Schau, 2005; O'Guinn and Muñiz, 2005).

- They usually attribute skills to themselves which traditionally have been reserved for the specialist or marketing director ( $\mathrm{O}^{\prime}$ Guinn and Muñiz, 2005). 
Among the outcomes of participation in virtual brand communities, they draw attention, in particular, to two of them: these communities facilitate the establishment of relationships founded upon trust (Casaló et al., 2007); and they favour consumer loyalty to the brand (Andersen, 2005; Jang et al., 2008; Shang et al., 2006) in detriment to the competitors (Thompson and Sinha, 2008).

Along similar lines, they have also studied the anti-brand virtual communities, which attract those consumers who are adverse to the meanings and values habitually associated with a particular brand (Hollenbeck and Zinkhan, 2006). Here, the brand name constitutes a negative symbol, which at times is related to the resistance of its members to large multinational firms. Under the auspices of the community, these consumers tend to act as activists and give voice to positions in opposition to the multinationals.

\subsection{Consumer behaviour in specific contexts}

Finally, we wish to make note of a line of investigation dedicated to the analysis, from a marketing point of view, of the effects on consumer behaviour associated with the use of concrete applications of the Social Web or of the presence of said applications in specific environments, such as avatars (McGoldrick et al., 2008; Vasalou and Joinson, 2009), blogs (Guadagno et al., 2008; Hsu and Lin, 2008; Lee et al., 2008; Rosanna et al., 2008; Yang, 2007), online games (Ho and Huang, 2009; Hsu and Lu, 2007; Koo, 2009; Molesworth, 2006; Weibel et al., 2008), virtual worlds (Bonsu and Darmody, 2008;), and spaces and profiles (Pfeil et al., 2009; Ross et al., 2009; Thelwall, 2008; Thomas et al., 2007; Zhao et al., 2008).

\section{Closing comments}

In this paper, we have presented and synthetically reviewed a diversity of research lines related to the Web-based consumer behaviour studies. In particular, special attention has been paid to the activities, experiences and behaviours of the consumers in the new context defined by the Web 2.0 and the applications of the Social Web.

We offer a wide view of research topics, analyzed from the marketing perspective and in line, particularly, with the consumer behaviour discipline, from the early nineties till now. This approach may be useful, not only to better structure or reinforce the knowledge academics have accumulated in the field, but also to serve as a guide and source of ideas for future researchers studying consumer behaviour within the Social Web environment. 
The first contributions to the study of consumer behaviour on the Web were preferably focused on obtaining user profiles and on the segmentation of the user community. However, shortly thereafter, questions more closely related to consumer behaviour were examined: the characteristics of the buyers on the Web, the determinants of the intention/decision to buy on the Web, the purchasing process itself on the Web, satisfaction and loyalty on the Web, trust in purchase decisions, and the adoption of classic theories and models to explain web-based consumer behaviour.

Within this interface between the Web and the consumer behaviour discipline, a new generation of studies can be situated, a collection of studies specifically examining consumer behaviour within the new environment defined by the Social Web. By considering the forms of interaction and relationship to the brand and the company within this new environment, they have, in the first place, identified the diverse forms in which these tools empower the consumer and the various patterns of behaviour on the part of the consumers in relation to such empowerment. In addition, an incipient line of investigation has arisen which explores the participation of the consumer in collective initiatives of innovation and generation of content based on the Social Web. Furthermore, a third line of investigation exists, one which is oriented to the study of consumer behaviour in personalization processes and which has highlighted the need to adapt the degree of personalization to the individual preferences of each consumer. A fourth and quite prominent line focuses its studies on virtual communities. Beyond the different classifications which have been proposed -especially by the investigations undertaken before the emergence of the latest generation of collaborative applications- some studies have analysed the nature and role of motivations and other determinants of participation in communities, while other studies have specifically examined the social networks established around commercial brands.

Although only a few empirical studies on brand communities have been carried out so far, various characteristics and behaviours linked to these communities, as well as their positive effects on brand confidence and loyalty, have been identified. Finally, we call attention to a fifth group of studies, focused on the study of consumer behaviour in applications or concrete environments of the Social Web.

\section{Managerial implications related to the Social Web and the consumers}


The emergence of the Web in the commerce arena is opening up new challenges and opportunities for businesses and marketing specialists. Moreover, the results obtained by the investigation carried out in the field of consumer behaviour on the Social Web have led to a number of recommendations relating to business practices.

Adopting a co-operative approach that promotes the empowerment of the consumer. Marketing programs should provide tools which allow the consumer to play a more active role in their relationship with the brand and the company. For example, they should make it possible for the consumer to perform advanced searches that are more efficient and effective, allowing the consumer to participate in the processes of value co-creation, or facilitating the diffusion of opinions and recommendations between consumers. In this way, these programs will better adapt to the needs of the new and empowered consumers, and for this reason the adoption of this co-operative approach ends up being especially advisable within the Social Web environment.

Considering consumers as a co-equal partner in the different facets of innovation. Marketing specialists must become familiar with the phenomenon of the social Web and consider the different ways in which the consumer can participate in innovation and creation of value (e.g.: generating ideas, collaborating in product design and testing, and providing product support). Likewise, it is worth considering forms of innovation born out of the generation of new contents.

Adapting the degrees of empowerment and personalization to each customer. Not all online consumers wish to play an active role in their relationship with companies, nor are they all willing to participate in exciting and complex initiatives which offer them products, services or personalized contents. For that reason, marketing specialists consider it essential to know the degree of empowerment and personalization desired by consumers on the Web and to provide them with an appropriate value offer.

Favouring the creation of brand communities. The development of an online community of participative consumers committed to the brand constitutes a powerful marketing tool. Not only does it contribute to more solid relationships between consumers, it also strengthens the relationships tying them to the brand, which in turn raises brand confidence and loyalty.

\section{References}

Acquisti, A.; Varian, H.R. (2005). "Conditioning prices on purchase history”, Marketing Science, Vol. 24, No. 3, pp. 367-381.

Ajzen, I.; Fishbein, M. (1980). Understanding attitudes and predicting social behaviour. Englewood Cliffs, New Jersey: Prentice Hall. 
Alba, J.; Lynch, J.; Weitz, B.; Janiszewski, C.; Lutz, R.; Sawyer, A.; Wood, S. (1997). "Interactive home shopping: consumer, retailer, and manufacturer incentives to participate in electronic marketplaces", Journal of Marketing, Vol. 61, No. 3, pp. 38-53.

Albors, J.; Ramos, J.C.; Hervas, J.L. (2008). "New learning network paradigms: communities of objectives, crowdsourcing, wikis and open source", International Journal of Information Management, Vol. 28, No. 3, pp. 194-202.

Aljifri, H.A.; Pons, A.; Collins, D. (2003). "Global e-commerce: a framework for understanding and overcoming the trust barrier", Information Management \& Computer Security, Vol. 11, No. 2/3, pp. 130138.

Alreck, P.; Settle, R. (2002). "The hurried consumer: time-saving perceptions of Internet and catalogue shopping", Journal of Database Marketing, Vol. 10, No. 1, pp. 25-35.

Andersen, P.H. (2005). "Relationship marketing and brand involvement of professionals through web-enhanced brand communities: the case of Coloplast”, Industrial Marketing Management, Vol. 34, No. 1, pp. 39-51.

Andersen, P.H. (2005). "Relationship marketing and brand involvement of professionals through web-enhanced brand communities: the case of Coloplast", Industrial Marketing Management, Vol. 34, No. 1, pp. 39-51.

Ansari, A.; Mela, C.F. (2003). "E-customization", Journal of Marketing Research, Vol. 40, No. 2, pp. 131-145.

Ashrafi, N.; Kuilboer, J.P. (2005). "Online privacy policies: an empirical perspective on self-regulatory practices", Journal of Electronic Commerce in Organizations, Vol. 3, No. 4, pp. 61-74.

Assael, H. (2005). "A demographic and psychographic profile of heavy Internet users and users by type of Internet usage", Journal of Advertising Research, Vol. 45, No. 1, pp. 93-123.

Attaran, M.; Vanlaar, I. (1999). "Privacy and security on the Internet: how to secure your personal information and company data", Information Management \& Computer Security, Vol. 7, No. 5, pp. 241-246.

Avery, RJ. (1996). "Determinants of search for non-durable goods: an empirical assessment of the economics of information theory", The Journal of Consumer Affairs, Vol. 30, No. 2, pp. 390-406.

Bagozzi, R. P.; Dholakia, U.M. (2002). "Intentional social action in virtual communities", Journal of Interactive Marketing, Vol. 16, No. 2, pp. 2- 21. 
Bakos, J.Y. (1997). "Reducing buyer search costs: implications for electronic marketplaces", Management Science, Vol. 43, No. 12, pp. 16761692.

Balabanis, G. and Vassileiou, S. (1999). "Some attitudinal predictors of home-shopping through the Internet", Journal of Marketing Management, Vol. 15, No. 5, pp. 361-385.

Bart, Y.; Shankar, V.; Sultan, F.; Urban, G.L. (2005). "Are the drivers and role of online trust the same for all web sites and consumers? A largescale exploratory empirical study", Journal of Marketing, Vol. 69, No. 4, pp. 133-152.

Bellman, S.; Lohse, G.L.; Johnson, E.J. (1999). "Predictors of online buying behaviour", Communications of the ACM, Vol. 42, No. 12, pp. 32-38.

Bendapudi, N.; Leone, R.P. (2003). "Psychological implications of customer participation in co-production", Journal of Marketing, Vol. 67, No. 1, pp. 14-28.

Benkler, Y. (2006). The wealth of networks - how social production transforms markets and freedom. New Haven, Connecticut: Yale University Press.

Betts, M. (2001). "Turning browsers into buyers", MIT Sloan Management Review, Vol. 42, No. 2, pp. 8-9.

Bhatnagar, A.; Misra, S.; Rao, H.R. (2000). "On risk, convenience, and Internet shopping behaviour", Communications of the ACM, Vol. 43, No. 11, pp. 98-105.

Bigné, E.; Ruiz, C.; Andreu, L. (2005). "Satisfacción y lealtad del consumidor online”, in Sánchez, M.; Gutiérrez, A. (Eds.), Marketing en Internet. Estrategia y empresa, pp. 201-235. Madrid, Spain: Pirámide.

Bishop, J. (2007). "Increasing participation in online communities: a framework for human-computer interaction", Computers in Human Behavior, Vol. 23, No. 4, pp. 1881-1893.

Blanchard, A.L. (2008). "Testing a model of sense of virtual community", Computers in Human Behavior, Vol. 24, No. 5, pp. 2107-2123.

Bonsu, S.K.; Darmody, A. (2008). "Co-creating Second Life: market_consumer cooperation in contemporary economy", Journal of Macromarketing, Vol. 28, No. 4, pp. 355-368.

Boulding, W.; Staelin, R.; Ehret, M.; and Johnston, W. J. (2005). "A customer relationship management roadmap: what is known, potential 
pitfalls, and where to go", Journal of Marketing, Vol. 69, No. 4, pp. 155166.

Brown, J.; Broderick, A.J.; Lee, N. (2007). "Word of mouth communication within online communities: conceptualizing the online social network", Journal of Interactive Marketing, Vol. 21, No. 3, pp. 2-20.

Brynjolfsson, E.; Smith, M.D. (2000). "Frictionless commerce? A comparison of Internet and conventional retailers", Management Science, Vol. 46, No. 4, pp. 563-585.

Burke, R.R. (1997). "Do you see what I see? The future of virtual shopping", Journal of the Academy of Marketing Science, Vol. 25, No. 4, pp. 352-360.

Butler, P.; Peppard, J. (1998). "Consumer purchasing on the Internet: processes and prospects". European Management Journal, Vol. 16, No. 5, pp. 600-610.

Carl, W.J. (2006). "What's all the buzz about?", Management Communication Quarterly, Vol. 19, No. 4, pp.601-634.

Casaló, L.; Flavián, C.; Guinalíu, M. (2007). "The impact of participation in virtual brand communities on consumer trust and loyalty: the case of free software", Online Information Review, Vol. 31, No. 6, pp. 775-792.

Castelfranchi, C. and Tan, Y. (2002). "The role of trust and deception in virtual societies", International Journal of Electronic Commerce, Vol. 6, No. 3, pp. 55-70.

Chang, J.; Samuel, N. (2004). "Internet shopping demographics and buying behaviour in Australia", Journal of American Academy of Business, Vol. 5, No. 1/2, pp. 171-176.

Chen, L.-D; Tan, J. (2004). "Technology adaptation in e-commerce: key determinants of virtual stores acceptance", European Management Journal, Vol. 22, No. 1, pp. 74-86.

Chen, S.; Dhillon, G. (2003). "Interpreting dimensions of consumer trust in e-commerce", Information Technology and Management, Vol. 4, No. 2/3, pp. 303-318.

Childers, T.L., Carr, C.L., Peck, J. and Carson, S. (2001). "Hedonic and utilitarian motivations for online retail shopping behavior", Journal of Retailing, Vol. 77, No. 4, pp. 511-535.

Cova, B.; Pace, S. (2006). "Brand community of convenience products: new forms of customer empowerment - the case 'my Nutella The 
Community",, European Journal of Marketing, Vol. 40, No. 9/10, pp. 1087-1105.

Cova, B.; Pace, S. (2006). "Brand community of convenience products: new forms of customer empowerment - the case 'my Nutella The Community", European Journal of Marketing, Vol. 40, No. 9/10, pp. 1087-1105.

Csikszentmihalyi, M. (1975). Beyond boredom and anxiety. San Francisco, California: Jossey-Bass.

Davis, F.D. (1989). "Perceived usefulness, perceived ease of use and user acceptance of information technology", MIS Quarterly, Vol. 13, No. 3, pp. 319-340.

Day, G.S. (1969). "A two-dimensional concept of brand loyalty", Journal of Advertising Research, Vol. 9, No. 3, pp. 29-36.

De Bruyn, A.; Lilien, G.L. (2008). "A multi-stage model of word-of-mouth influence through viral marketing", International Journal of Research in Marketing, Vol. 25, No. 3, pp. 151-163.

Deck, C.A.; Wilson, B.J. (2006). "Tracking customer search to price discriminate", Economic Inquiry, Vol. 44, No. 2, pp. 280-295.

Dellaert, B.G.C.; Stremersch, S. (2005). "Marketing mass-customized products: striking a balance between utility and complexity", Journal of Marketing Research, Vol. 42, No. 2, pp. 219-227.

Dholakia, R.; Uusitalo, O. (2002). "Switching to electronic stores: consumers characteristics and the perception of shopping benefits", International Journal of Retail and Distribution Management, Vol. 27, No. 4, pp. 154-165.

Dholakia, U.M.; Bagozzi, R.P.; Pearo, L.K. (2004). "A social influence model of consumer participation in network- and small-group-based virtual communities", International Journal of Research in Marketing, Vol. 21, No. 3, pp. 241-263.

Donthu, N. (2001). "Does your website measure up?", Marketing Management, Vol. 10, No. 4, pp. 29-32.

Donthu, N.; Garcia, A. (1999). "The Internet shopper", Journal of Advertising Research, Vol. 39, No. 3, pp. 52-58.

Dou, W.; Krishnamurthy, S. (2007). "Using brand websites to build brands online: a product versus service brand comparison", Journal of Advertising Research, Vol. 47, No. 2, pp. 193-206. 
Dwyer, P. (2007). "Measuring the value of electronic word of mouth and its impact in consumer communities", Journal of Interactive Marketing, Vol. 21, No. 2, pp. 63-79.

Fishbein, M.; Ajzen, I. (1975). Belief, attitude, intention, and behaviour: an introduction to theory and research. Reading, Massachusetts: AddisonWesley.

Flavián, C.; Guinalíu, M. (2005). "The influence of virtual communities on distribution strategies in the Internet", International Journal of Retail \& Distribution Management, Vol. 33, No. 6, pp. 405-425.

Floh, A; Treiblmaier, H. (2006). "What keeps the e-banking customer loyal? A multigroup analysis of the moderator role of consumer characteristics on e-loyalty in the financial service industry", Journal of Electronic Commerce Research, Vol. 7, No. 2, pp. 97-110.

Forsythe, S.; Shi, B. (2003). "Consumer patronage and risk perceptions in Internet shopping", Journal of Business Research, Vol. 56, No. 11, pp. 867-875.

Garbarino, E.; Lee, O.F. (2003). "Dynamic pricing in Internet retail: effects on consumer trust", Psychology \& Marketing, Vol. 20, No. 6, pp. 495-513.

Gatignon, H.; Robertson, T.S. (1985). "A propositional inventory for new diffusion research", Journal of Consumer Research, Vol. 11, No. 4, pp. 849-867.

Gefen, D.; Straub, D. W. (1997). "Gender differences in the perception and use of e-mail: an extension to the technology acceptance model", MIS Quarterly, Vol. 21, No. 4, pp. 389-400.

George, J.F. (2002). "Influence on the intent to make Internet purchase", Internet Research: Electronic Networking Applications and Policy, Vol. 12 , No. 2, pp. 165-180.

George, J.F. (2004). "The theory of planned behaviour and Internet purchasing", Internet Research, Vol. 14, No. 3, pp. 198-212.

Goldsmith, R.E.; Bridges, E. (2000). "E-tailing vs. retailing: using attitude to predict online buying behaviour", Quarterly Journal of Electronic Commerce, Vol. 1, No. 3, pp. 245-253.

Goldsmith, R.E.; Goldsmith, E.B. (2002). "Buying apparel over the Internet", Journal of Product \& Brand Management, Vol. 11, No. 2, pp. 89-102.

Grabner-Kraeuter, S. (2002). "The role of consumers' trust in onlineshopping", Journal of Business Ethics, Vol. 39, No. 1/2, pp. 43-50. 
Grewal, D.; Munger, J.L.; Iyer, G.R.; Levy, M. (2003). "The influence of Internet-retailing factors on price expectations", Psychology \& Marketing, Vol. 20, No. 6, pp. 477-493.

Gritzalis, S. (2004). "Enhancing Web privacy and anonymity in the digital era", Information Management \& Computer Security, Vol. 12, No. 2/3, pp. 255-288.

Guadagno, R.E.; Okdie, B.M.; Eno, C.A. (2008). "Who blogs? Personality predictors of blogging", Computers in Human Behavior, Vol. 24, No. 5, pp. 1993-2004.

Ha, H. (2004). "Factors influencing consumer perceptions of brand trust online", Journal of Product and Brand Management, Vol. 13, No. 5, pp. 329-342.

Hagel, J. III; Armstrong, A.G. (1997). Net gain: expanding markets through virtual communities. Boston, Massachusetts: Harvard Business School Press.

Hammond, K.; McWilliam, G.; Diaz, A.N. (1998). "Fun and work on the Web: differences in attitudes between novices and experienced users", Advances in Consumer Research, Vol. 25, No. 1, pp. 372-378.

Harrison, T., Waite, K. and Hunter, G.L. (2006). "The Internet, information and empowerment", European Journal of Marketing, Vol. 40, No. 9/10, pp.972-993.

Hars, A.; Qu, S. (2002). "Working for free? Motivations for participating in open-source projects", International Journal of Electronic Commerce, Vol. 6, No. 3, pp. 25-39.

Helander, M. and Khalid, H. (2000). "Modelling the customer in electronic commerce”, Applied Ergonomics, Vol. 31, No. 6, pp. 609-619.

Herrero, A.H.; Rodríguez del Bosque, I.A. (2008). "Explaining B2C ecommerce acceptance: an integrative model based on the framework by Gatignon and Robertson", Interacting with Computers, Vol. 20, No. 2, pp. 212-224.

Ho, S.-H.; Huang, C.-H. (2009). "Exploring success factors of video game communities in hierarchical linear modeling: the perspectives of members and leaders", Computers in Human Behavior, Vol. 25, No. 3, pp. 761-769.

Hoffman, D.; Kalsbeek, W.; Novak, T. (1996). "Internet and Web use in the U.S.”, Communications of the ACM, Vol. 39, No. 12, pp. 36-46. 
Hoffman, D.; Novak, T. (1996). "Marketing in hypermedia computermediated environments: conceptual foundations", Journal of Marketing, Vol. 60, No. 3, pp. 50-68.

Hoffman, D.; Novak, T. (1997). "A new paradigm for electronic commerce", The Information Society, Vol. 13, No. 1, pp. 43-54.

Hoffman, D.; Novak, T.; Peralta, M. (1999a). "Information privacy in the marketspace: implications for the commercial uses of anonymity on the Web", The Information Society, Vol. 15, No., 2, pp. 129-139.

Hoffman, D.; Novak, T.; Peralta, M. (1999b). "Building consumer trust in online environments: the case for information privacy", Communications of the ACM, Vol. 42, No. 4, pp. 80-85.

Hollenbeck, C.R.; Zinkhan, G.M. (2006). "Consumer activism on the Internet: the role of anti-brand communities", Advances in Consumer Research, Vol. 33, No. 1, pp. 479-485.

Holt, D.B. (2004). How brands become icons: the principles of cultural branding. Boston, Massachusetts: Harvard Business School Press.

Hsu, C.-L.; Lin, J.C-C. (2008). "Acceptance of blog usage: the roles of technology acceptance, social influence and knowledge sharing motivation", Information \& Management, Vol. 45, No. 1, pp. 65-74.

Hsu, C.-L.; Lu, H.-P. (2007). "Consumer behavior in online game communities: a motivational factor perspective", Computers in Human Behavior, Vol. 23pp. 1642-1659.

Iyengar, J.V. (2004). "A discussion of current and potential issues relating information security for Internet communications", Competitiveness Review, Vol. 14, No. 1/2, pp. 90-95.

Jacoby, J (1971). "A model of multi-brand loyalty", Journal of Advertising Research, Vol. 11, No. 3, pp. 25-31.

Jacoby, J.; Chestnut, R.W. (1978). Brand loyalty: measurement and management. New York: John Wiley and Sons.

Jang, H.; Olfman, L.; Ko, I.; Koh, J.; Kim, K. (2008). "The influence of online brand community characteristics on community commitment and brand loyalty", International Journal of Electronic Commerce, Vol. 12, No. 3, pp. 57-80.

Jarvenpaa, S., Tractinsky, N., Saarinen, L. and Vitale, M. (2000). "Consumer trust in an Internet store", Information Technology and Management, Vol. 1, No. 1/2, pp. 45-71. 
Jarvenpaa, S.; Tractinsky, N.; Saarinen, L.; Vitale, M. (1999). "Consumer trust in an Internet store: a cross-cultural validation", Journal of Computer-Mediated Communications, Vol. 5, No. 2. Available at http://www.ascusc.org/jcmc/vol5/issue2/jarvenpaa.htm.

Jarvenpaa, S.L.; Todd, P.A. (1997). "Is there a future for retailing on the Internet?", in Peterson, R.S. (Ed.), Electronic Marketing and the Consumer, pp. 139-156. Thousand Oaks, California: Sage.

Jeppesen, L.B.; Frederiksen, L. (2006). "Why do users contribute to firmhosted user communities? The case of computer-controlled music instruments", Organization Science, Vol. 17, No. 1, pp. 45-63.

Jepsen, A.L. (2006). "Information search in virtual communities: is it replacing use of off-line communication?", Journal of Marketing Communications, Vol. 12 No. 4, pp. 247-61.

Jiang, P. (2002). "A model of price search behaviour in electronic marketplace", Internet Research, Vol. 12, No. 2, pp. 181-190.

Johnson, K.K.P.; Lennon, S.J.; Jasper, C.; Damhorst, M.L.; Lakner, H.B. (2003). "An application of Rogers's innovation model: use of the Internet to purchase apparel, food, and home furnishing products by small community consumers", Clothing and Textiles Research Journal, Vol. 21, No. 4, pp. 185-96.

Kamali, N.; Loker, S. (2002). "Mass customization: on-line consumer involvement in product design", Journal of Computer-Mediated Communication, Vol. 7, No. 4. Available at http://jcmc.indiana.edu/vol7/issue4/loker.html.

Karjaluoto, H.; Mattila, M.; Pento, T. (2002). "Factors underlying attitude formation towards online banking in Finland", The International Journal of Bank Marketing, Vol. 20, No. 6, pp. 261-272.

Katz, J.E.; Rice, R.E.; Aspden, P. (2001). "The Internet, 1995-2000: access, civic involvement, and social interaction", The American Behavioral Scientist, Vol. 45, No. 3, pp. 405-422.

Kau, A.K.; Tang, Y.T.; Ghose, S. (2003). "Typology of online shoppers", The Journal of Consumer Marketing, Vol. 20, No. 2/3, pp. 139-156.

Kim, H.-S.; Park, J.Y.; Jin, B. (2008). "Dimensions of online community attributes: examination of online communities hosted by companies in Korea", International Journal of Retail \& Distribution Management, Vol. 36, No. 10, pp. 812-830. 
Kim, Y.K.; Kim, E.Y.; Kumar, S. (2003). "Testing the behavioral intentions model of online shopping for clothing", Clothing and Textiles Research Journal, Vol. 21, No. 1, pp. 32-40.

Kımıloğlu, H. (2004). "The 'e-literature': a framework for understanding the accumulated knowledge about Internet marketing", Academy of Marketing Science Review, Vol. 4, No. 6 Available at http://www.amsreview.org/articles/kimiloglu06-2004.pdf.

King, A.B. (2001). "Affective dimensions of Internet culture", Social Science Computer Review, Vol. 19, No. 4, pp. 414-430.

Koehn, D. (2003). "The nature of and conditions for online trust", Journal of Business Ethics, Vol. 43, No. 1/2, pp. 3-19.

Koh, J.; Kim, Y.-G. (2003). "Sense of virtual community: a conceptual framework and empirical validation", International Journal of Electronic Commerce, Vol. 8, No. 2, pp. 75-93.

Koo, D.-M. (2009). "The moderating role of locus of control on the links between experiential motives and intention to play online games", Computers in Human Behavior, Vol. 25, No. 2, pp. 466-474.

Kozinets, R.V. (1999). "E-tribalized marketing?: the strategic implications of virtual communities of consumption", European Management Journal, Vol. 17, No. 3, pp. 252-264.

Kozinets, R.V.; Hemetsberger, A.; Schau, H.J. (2008). "The wisdom of consumer crowds: collective innovation in the age of networked marketing", Journal of Macromarketing, Vol. 28, No. 4, pp. 339-354.

Kruck, S.E.; Gottovi, D.; Moghadami, F.; Broom, R.; Forcht, K.A. (2002). "Protecting personal privacy on the Internet", Information Management \& Computer Security, Vol. 10, No. 2/3, pp. 77-84.

Larson, L.; Larson, R.; Greenlee, J. (2003). "Privacy protection on the Internet”, Strategic Finance, Vol. 84, No. 12, pp. 49-53.

Lee, D.-H.; Im, S.; Taylor, C.R. (2008). "Voluntary self-disclosure of information on the internet: a multimethod study of the motivations and consequences of disclosing information on blogs", Psychology \& Marketing, Vol. 25, No. 7, pp. 692-710.

Lee, M.; Turban, E. (2001). "A trust model for consumer Internet shopping", International Journal of Electronic Commerce, Vol. 6, No. 1, pp. 75-91.

Lévy, P. (1997). Collective intelligence: mankind's emerging world in cyberspace. Cambridge, Massachusetts: Perseus. 
Li, H.; Kuo, C.; Russell, M. (1999). "The impact of perceived channel utilities, shopping orientations and demographics on the consumer's online buying behaviour", Journal of Computer Mediated Communications, Vol. 5, No. 2. Available at http://www.ascuc.org/jcmc/vol5/issue2/hairong.html.

Liao, Z.; Cheung, T. (2001). "Internet-based e-shopping and consumer attitudes: an empirical study", Information and Management, Vol. 38, No. 5, pp. 299-306.

Limayem, M.; Khalifa, M.; Frini, A. (2000). "What makes consumers buy from Internet? A longitudinal study of online shopping", IEE Transaction on Systems, Man, and Cybernetics, Vol. 30, No. 4, pp. 421-432.

Lin, H.-F. (2007). "The role of online and offline features in sustaining virtual communities: an empirical study", Internet Research, Vol. 17, No. 2, pp. 119-138.

Liu, C.; Arnett, K.P. (2000). "Exploring the factors associated with Web site success in the context of electronic commerce", Information \& Management, Vol. 38, No. 1, pp. 23-34.

Long, M.; McMellon, C. (2004). "Exploring the determinants of retail service quality on the Internet", The Journal of Services Marketing, Vol. 18 , No. 1, pp. 78-90.

Lynch, P.D.; Kent, R.J.; Srinivasan, S.S. (2001). "The global Internet shopper: evidence from shopping tasks in twelve countries", Journal of Advertising Research, Vol. 41, No. 4, pp. 15-23.

Macaulay, L.A.; Keeling, K.; McGoldrick, P.; Dafoulas, G.; Kalaitzakis, E.; Keeling, D. (2007). "Co-evolving e-tail and on-line communities: conceptual framework", International Journal of Electronic Commerce, Vol. 11, No. 4, pp. 53-77.

Maignan, I.; Lukas, B. (1997). "The nature and social uses of the Internet: a qualitative investigation", Journal of Consumer Affairs, Vol. 31, No. 2, pp. 346-371.

Martínez-López, F.J.; Luna, P.; Martínez, F.J. (2005). “Online shopping, the standard learning hierarchy, and consumers' Internet expertise: an American-Spanish comparison", Internet Research, Vol. 15, No. 3, pp. 312-334.

Martínez-López, F.J.; Luna, P.; Martínez, F.J. (2006). "Motivations for consumption behaviours on the Web: a conceptual model based on a holistic approach", International Journal of Electronic Marketing and Retailing, Vol. 1, No. 1, pp. 3-20. 
Mathwick, C.; Malhotra, N.K.; Rigdon, E. (2002). "The effect of dynamic retail experiences on experiential perceptions of value: an Internet and catalog comparison", Journal of Retailing, Vol. 78, No. 1, pp. 51-60.

Mayer, R.N. (2002). "Shopping from a list: international studies of consumer online experiences", Journal of Consumer Affairs, Vol. 36, No. 1, pp. 115-126.

McAlexander, J. ; Kim, S. ; Roberts, S. (2003). "Loyalty: the influence of satisfaction and brand community integration", Journal of Marketing Theory \& Practice, Vol. 11, No. 4, pp. 1-11.

McAlexander, J.H.; Schouten, J.W.; Koenig, H.F. (2002). "Building brand community", Journal of Marketing, Vol. 66, No. 1, pp. 38-54.

McAlexander; J.H., Schouten, J.W.; Koenig, H.F. (2002). "Building brand community”, Journal of Marketing, Vol. 66, No. 1, pp. 38-54.

McGoldrick, P.J.; Keeling, K.A.; Beatty, S.F. (2008). “A typology of roles for avatars in online retailing", Journal of Marketing Management, Vol. 24, No. 3/4, pp. 433-461.

McKinney, V.; Yoon, K.; Zahedi, F. (2002). "The measurement of Webcustomer satisfaction: an expectation and disconfirmation approach", Information Systems Research, Vol. 13, No. 3, pp. 296-315.

McKnight, D.; Choudhury, V.; Kacmar, C. (2002). "Developing and validating trust measures for e-commerce: an integrative typology", Information Systems Research, Vol. 13, No. 3, pp. 334-359.

McKnight, H.; Chervany, N. (2001). "What trust means in e-commerce customer relationships: an interdisciplinary conceptual typology", International Journal of Electronic Commerce, Vol. 6, No. 2, pp. 35-59.

McWilliam, G. (2000). "Building stronger brands through online communities", Sloan Management Review, Vol. 41, No. 3, pp. 43-54.

McWilliam, G. (2000). "Building stronger brands through online communities", Sloan Management Review, Vol. 41, No. 3, pp. 43-54.

Miceli, G.N.; Ricotta, F.; Costabile, M. (2007). "A conceptual framework for interactive personalization", Journal of Interactive Marketing, Vol. 21, No. 2, pp. 6-25.

Miyazaki, A.D. (2003). "Guest editorial: the psychology of pricing on the Internet”, Psychology \& Marketing, Vol. 20, No. 6, pp. 471-476.

Miyazaki, A.D.; Fernandez, A. (2001). "Consumer perceptions of privacy and security risks for online shopping", The Journal of Consumer Affairs, Vol. 35, No. 1, pp. 27-44. 
Molesworth, M. (2006). "Real brands in imaginary worlds: investigating players' experiences of brand placement in digital games", Journal of Consumer Behaviour, Vol. 5, No. 4, pp. 355-366.

Montoya-Weis, M.; Voss, G.; Grewall, D. (2003). "Determinants of online channel use and overall satisfaction with a relational, multichannel service provider", Journal of the Academy of Marketing Science, Vol. 31, No. 4, pp. 448-458.

Muñiz, A.M. Jr.; Hamer, L.O. (2001). "Us versus them: oppositional brand loyalty and the cola wars", Advances in Consumer Research, Vol. 28, No. 1, pp. 355-361.

Muñiz, A.M. Jr.; O'Guinn, T.C. (2001). "Brand community", Journal of Consumer Research, Vol. 27, No. 4, pp. 412-432.

Muñiz, A.M. Jr.; Schau, H.P. (2005), "Religiosity in the abandoned Apple Newton brand community", Journal of Consumer Research, Vol. 31, No. 4, pp. 737-747.

Nakra, P. (2001). "Consumer privacy rights: CPR and the age of the Internet”, Management Decision, Vol. 39, No. 4, pp. 272-278.

Nambisan, S. (2002). "Designing virtual customer environments for new product development: toward a theory", Academy of Management Review, Vol. 27, No. 3, pp. 392-413.

Nambisan, S.; Baron, R.A. (2007). "Interactions in virtual customer environments: implications for product support and customer relationship management", Journal of Interactive Marketing, Vol. 21, No. 2, pp. 42-62.

Newholm, T.; McGoldrick, P.; Keeling, K.; Macaulay, L.; Doherty, J. (2004). "Multi-story trust and online retailer strategies", International Review of Retail, Distribution \& Consumer Research, Vol. 14, No. 4, pp. 437-456.

Novak, T.; Hoffman, D.; Yung, Y. (2000). "Measuring the customer experience in online environments: a structural modelling approach", Marketing Science, Vol. 19, No. 1, pp. 22-42.

O'Cass, A.; Fenech, T. (2003). "Web retailing adoption: exploring the nature of interest users Web retailing behaviour", Journal of Retailing and Consumer Services, Vol. 10, No. 2, pp. 81-94.

O'Guinn, T.C.; Muñiz, A.M. Jr. (2005). "Communal consumption and the brand", in Ratneshwar, S.; Mick, D.G. (Eds), Inside consumption: frontiers of research on consumer motives, goals and desires, pp. 252-272. New York: Routledge. 
Oliver, R.L. (1999). "Whence consumer loyalty?", Journal of Marketing, Vol. 63, No. 4, pp. 33-44.

Oreg, S.; Nov, O. (2008). "Exploring motivations for contributing to open source initiatives: the roles of contribution context and personal values", Computers in Human Behavior, Vol. 24, No. 5, pp. 2055-2073.

Patterson, P.G.; Johnson, L.W.; Spreng, R.A. (1997). "Modelling the determinants of customer satisfaction for business to business professional services", Journal of the Academy of Marketing Science, Vol. 25, No. 1, pp. 4-17.

Pavlou, P.A. (2003). "Consumer acceptance of electronic commerce: integrating trust and risk with the technology acceptance model", International Journal of Electronic Commerce, Vol. 7 No. 3, pp. 101-134.

Payne, A.F.; Storbacka, K.; Frow, P. (2008). "Managing the co-creation of value", Journal of the Academy of Marketing Science, Vol. 36, No. 1, pp. 83-96.

Peppers, D.; Rogers, M. (1993). The one-to-one future: building relationships one customer at a time. New York: Currency/Doubleday.

Perea y Monsuwé, T.; Dellaert, B.; De Ruyter, K. (2004). "What drives consumers to shop online? A literature review", International Journal of Service Industry Management, Vol. 15, No. 1, pp. 102-121.

Pfeil, U.; Arjan, R.; Zaphiris, P. (2009). "Age differences in online social networking - A study of user profiles and the social capital divide among teenagers and older users in MySpace", Computers in Human Behavior, Vol. 25, No. 3, pp. 643-654.

Phillips, J.T. (2002). "Privacy vs. cybersecurity", Information Management Journal, Vol. 36, No. 3, pp. 46-50.

Piller, F.; Schubert, P.; Koch, M.; Möslein, K. (2005). "Overcoming mass confusion: collaborative customer co-design in online communities", Journal of Computer-Mediated Communication, Vol. 10, No. 4. Available at http://jcmc.indiana.edu/vol10/issue4/piller.html.

Pine, J. B. (1993). Mass customization. The new frontier of business competition. Boston, Massachusetts: Harvard University Press.

Pires, G.D.; Stanton, J.; Rita, P. (2006). "The Internet, consumer empowerment and marketing strategies", European Journal of Marketing, Vol. 40, No. 9/10, pp. 936-949. 
Pitt, L.F.; Berthon, P.R.; Watson, T.R.; Zinkhan, G. (2002). "The Internet and the birth of real consumer power", Business Horizons, Vol. 45, No. 6, pp. 7-14.

Pitta, D.A. and Fowler, D. (2005). "Online consumer communities and their value to new product developers", Journal of Product \& Brand Management, Vol. 14, No. 5, pp. 283-291.

Plant, R.; Willcocks, L.; Olson, N. (2003). "Measuring e-business performance: towards a revised balanced scorecard approach", Information Systems and E-business Management, Vol. 1, No. 3, pp. 265281.

Porter, C.E. (2004). "A typology of virtual communities: a multidisciplinary foundation for future research", Journal of ComputerMediated Communication, Vol. 10, No. 1. Available at http://jcmc.indiana.edu/vol10/issue1/porter.html.

Postmes, T.; Spears, R.; Lea, M. (2000). "The formation of group norms in computer-mediated communication", Human Communication Research, Vol. 26, No. 3, pp. 341-371.

Prahalad, C.K.; Ramaswamy, V. (2004). "Co-creation experiences: the next practice in value creation", Journal of Interactive Marketing, Vol. 18, No. 3, pp. 5-14.

Randall, T.; Terwiesch, C.; Ulrich, K.T. (2005). "Principles for user design of customized products", California Management Review, Summer, Vol. 47, No. 4, pp. 68-85.

Reynolds, J. (2000). "Ecommerce: a critical review", International Journal of Retail and Distribution Management, Vol. 28, No. 10, pp. 417-444.

Rezabakhsh, B.; Bornemann, D.; Hansen, U.; Schrader, U. (2006). "Consumer power: a comparison of the old economy and the Internet economy", Journal of Consumer Policy, Vol. 29, No. 1, pp. 3-36.

Rheingol, H. (2002). Smart mobs: the next social revolution. Cambridge, Massachusetts: Perseus.

Ridings, C.M.; Gefen, D. (2004). "Virtual community attraction: why people hang out online", Journal of Computer Mediated Communication, Vol. 10, No. 1. Available at http://jcmc.indiana.edu/vol10/issue1/ridings gefen.html.

Rodríguez del Bosque, I.; Herrero, A. (2005). "La aceptación de Internet y el comercio electrónico basado en las actitudes", in Sánchez, M.; Gutiérrez, A. (Eds.), Marketing en Internet. Estrategia y empresa, pp. 371-412. Madrid, Spain: Pirámide. 
Rodríguez-Ardura, I.; Martínez-López, F.J. (2008). "Playing cat and mouse: consumer empowerment and marketing interaction on the Net", International Journal of Business Environment, Vol. 2, No. 2, pp. 201214.

Ross, C.; Orr, E.S.; Sisic, M.; Arseneault, J.M.; Simmering, M.G.; Orr, R.R. (2009). "Personality and motivations associated with Facebook use", Computers in Human Behavior, Vol. 25, No. 2, pp. 578-586.

Rowley, J. (2000). "Product searching with shopping bots", Internet Research: Electronic Networking Applications and Policy, Vol. 10, No. 3, pp. 203-214.

Rowley, J.; Kupiec-Teahan, B. and Leeming, E. (2007). "Customer community and co-creation: a case study", Marketing Intelligence \& Planning, Vol. 25, No. 2, pp. 136-146.

Sánchez-Franco, M.J. (2006). "Exploring the influence of gender on the web usage via partial least squares", Behaviour \& Information Technology, Vol. 25, No. 1, pp. 19-36.

Sánchez-Franco, M.J.; Roldán, J.L. (2005). "Web acceptance and usage model: a comparison between goal-directed and experiential Web users", Internet Research, Vol. 15, No. 1, pp. 21-48.

Schaupp, L.C.; Bélanger, F. (2005). "A conjoint analysis of online consumer satisfaction", Journal of Electronic Commerce Research, Vol. 6, No. 2, pp. 95-111.

Schifter, D.B.; Ajzen, I. (1985). "Intention, perceived control, and weight loss: an application of the Theory of Planned Behavior", Journal of Personality and Social Psychology, Vol. 49, No. 3, pp. 842-851.

Schoberth, T.; Heinzl, A.; Preece, J. (2006). "Exploring communication activities in online communities: a longitudinal analysis in the financial services industry", Journal of Organizational Computing and Electronic Commerce, Vol. 16, No. 3/4, pp. 247-265.

Scullin, S.; Fjermestad, J.; Romano, N.C. (2004). "E-relationship marketing: changes in traditional marketing as an outcome of electronic customer relationship management", Journal of Enterprise Information Management, Vol. 17, No. 2, pp. 410-415.

Sen, R.; King, R.C.; Shaw, M.J. (2006). "Buyers' choice of online search strategy and its managerial implications", Journal of Management Information Systems, Vol. 23, No. 1, pp. 211-238. 
Shang, R.-A.; Chen, Y.-C.; Liao, H.-J. (2006). "The value of participation in virtual consumer communities on brand loyalty", Internet Research, Vol. 16, No. 4, pp. 398-418.

Shankar, V; Urban, G.; Sultan, F. (2002). "Online trust: a stakeholder perspective, concepts, implications, and future directions", The Journal of Strategic Information Systems, Vol. 11, No. 34, pp. 325-344.

Shih, Y.; Fang, K. (2004). "The use of a decomposed theory of planned behaviour to study Internet banking in Taiwan", Internet Research, Vol. 14, No. 3, pp. 213-223.

Shim, S.; Estlick, M.A.; Lotz, S.L.; Warrington, P. (2001). "An online prepurchase intentions model: the role of intention to search", Journal of Retailing, Vol. 77, No. 33, pp. 397-416.

Sicilia, M.; Palazon, M. (2008). "Brand communities on the internet: a case study of Coca-Cola's Spanish virtual community", Corporate Communications: An International Journal, Vol. 13, No. 3, pp. 255-270.

Sorce, P.; Perotti, V.; Widrick, S. (2005). "Attitude and age differences in online buying", International Journal of Retail \& Distribution Management, Vol. 33, No. 2/3, pp. 122-132.

Srinivassan, S.; Anderson, R.; Ponnavolu, K. (2002). "Customer loyalty in e-commerce: an exploration of its antecedents and consequents", Journal of Retailing, Vol. 78, No. 1, pp. 41-50.

Surjadjaja, H.; Gosh, S.; Anthony, F. (2003). "Determinants and assessing the determinants of e-service operations", Managing Service Quality, Vol. 13, No. 1, pp. 39-53.

Swaminathan,V.; Lepkowska-White, E.; Rao, B. (1999). "Browsers or buyers in cyberspace? An investigation of factors influencing electronic exchange", Journal of Computer Mediated Communications, Vol. 5, No. 2. Available at http://jcmc.indiana.edu/vol5/issue2/swaminathan.htm.

Swinyard, W.R.; Smith, S.M. (2003). "Why people (don't) shop online: a lifestyle study of the Internet consumer", Psychology \& Marketing, Vol. 20, No. 7, pp. 567-597.

Szmigin, I.; Reppel, A.E. (2004), "Internet Community bonding: the case of macnews.de," European Journal of Marketing, Vol. 38, No. 5/6, pp. 62640 .

Tan, Y.; Thoen, W. (2000). "Toward a generic model of trust for electronic commerce", International Journal of Electronic Commerce, Vol. 5, No. 2, pp. 61-74. 
Taylor, S.; Todd, P.A. (1995). "Understanding information technology usage: a test of competing models", Information Systems Research, Vol. 6, No. 2, pp. 144-176.

Teo, T. (1998). "Differential effects of occupation on Internet usage", Internet Research, Vol. 8, No. 2, pp. 156-165.

Teo, T. (2001). "Demographic and motivation variables associated with Internet usage activities", Internet Research, Vol. 11, No. 2, pp. 125-137.

Teo, T.; Lim, V. (1997). "Usage patterns and perceptions of the Internet: the gender gap", Equal Opportunities International, Vol. 16, No. 6/7, pp. 1-8.

Thelwall, M. (2008). "Social networks, gender, and friending: an analysis of MySpace member profiles", Journal of the American Society for Information Science and Technology, Vol. 59, No. 8, pp. 1321-1330.

Thomas, J.B.; Peters, C.O.; Tolson, H. (2007). "An exploratory investigation of the virtual community MySpace.com: what are consumers saying about fashion?", Journal of Fashion Marketing and Management, Vol. 11, No. 4, pp. 587-603.

Thompson, S.A; Sinha, R.K. (2008). "Brand communities and new product adoption: the influence and limits of oppositional loyalty", Journal of Marketing, Vol. 72, No. 6, pp. 65-80.

Trocchia, P.J.; Janda, S. (2000). "A phenomenological investigation of Internet usage among older individuals", The Journal of Consumer Marketing, Vol. 17, No. 7, pp. 605-616.

Trocchia, P.J.; Janda, S. (2003). "How do consumers evaluate Internet retail service quality?", The Journal of Service Marketing, Vol. 17, No. 2/3, pp. 243-253.

Udo, G.J. (2001). "Privacy and security concerns as major barriers for ecommerce: a survey study", Information Management \& Computer Security, Vol. 9, No. 4, pp. 165-174.

Urban, G.; Sultan, F.; Qualls, W. (2000). "Placing trust at the center of your Internet Strategy", Sloan Management Review, Vol. 42, No. 1, pp. 39-48.

Van Iwaarden, J.; Van Der Wiele, T.; Ball, L.; Millen, R. (2003). "Applying SERVQUAL to Web sites: an exploratory study", The International Journal of Quality \& Reliability Management, Vol. 20, No. 8/9, pp. 919935.

Vargo, S.L.; Lusch, R.F. (2004). "Evolving to a new dominant logic for marketing”, Journal of Marketing, Vol. 68, No. 1, pp. 1-17. 
Vasalou, A.; Joinson, A.N. (2009). "Me, myself and I: the role of interactional context on self-presentation through avatars", Computers in Human Behavior, Vol. 25, No. 2, pp. 510-520.

Vellido, A.; Lisboa, P.; Meehan, K. (2000). "Quantitative characterization and prediction of online purchasing behaviour: a latent variable approach", International Journal of Electronic Commerce", Vol. 4, No. 4, pp. 83-104.

Venkatesh, V.; Morris, M. (2000). "Why don't men ever stop to ask for directions? Gender, social influence, and their role in technology acceptance and usage behaviour", MIS Quarterly, Vol. 24, No. 1, pp. 115139.

Vesanen, J.; Raulas, M. (2006). "Building bridges for personalization: A process model for marketing", Journal of Interactive Marketing, Vol. 20, No. 1, pp. 5-20.

Vijayasarathy, L.R.; Jones, J.M. (2000). "Print and Internet catalog shopping: assessing attitudes and intentions", Internet Research, Vol. 10, No. 3, pp. 191-202.

Vuori, S.; Holmlund-Rytkönen, M. (2005). "55+ Internet users", Marketing Intelligence and Planning, Vol. 23, No. 1, pp. 58-76.

Wakefield, R.L.; Whitten, D. (2006). "Examining user perceptions of thirdparty organization credibility and trust in an e-retailer", Journal of Organizational and End User Computing, Vol. 18, No. 2, pp. 1-19.

Wang, H.; Lee, M.K.O.; Wang, C. (1998). "Consumer privacy concerns about Internet marketing", Communications of the ACM, Vol. 41, No. 3, pp. 63-70.

Wasko, M.M.; Faraj, S. (2000). “'It is what one does': why people participate and help others in electronic communities of practice", The Journal of Strategic Information Systems, Vol. 9, No. 2/3, pp. 155-173.

Weibel, D.; Wissmath, B.; Habegger, S.; Steiner, Y.; Groner, R. (2008). "Playing online games against computer- vs. human-controlled opponents: effects on presence, flow, and enjoyment", Computers in Human Behavior, Vol. 24, No. 5, pp. 2274-2291.

Wenger, E. (1998). Communities of practice: learning, meaning, and identity. Cambridge, United Kingdom: Cambridge University Press.

Whitly, B.E., Jr. (1997). "Gender differences in computer related attitudes and behavior: a meta analysis", Computers in Human Behavior, Vol. 13, No. 1, pp. 1-22. 
Wind, J.; Rangaswamy, A. (2001). "Customerization: the next revolution in mass customization", Journal of Interactive Marketing, Vol. 15, No. 1, pp. 13-32.

Winer, R.S. (2001). "A framework for customer relationship management", California Management Review, Vol. 43, No. 4, pp. 89-105.

Wolfinbarger, M.; Gilly, M. (2001). "Shopping online for freedom, control, and fun", California Management Review, Vol. 43, No. 2, pp. 35-55.

$\mathrm{Wu}$, S. (2003). "The relationship between consumer characteristics and attitude toward online shopping", Marketing Intelligence and Planning, Vol. 21, No. 1, pp. 37-44.

Xu, B.; Jones, D.R.; Shao, B. (2009). "Volunteers' involvement in online community based software development", Information \& Management, Vol. 46, No. 3, pp. 151-158.

Yang, K.C.C. (2007). "Factors influencing Internet users' perceived credibility of news-related blogs in Taiwan", Telematics and Informatics, Vol. 24, No. 2, pp. 69-85.

Yang, Z.; Jun, M. (2002). "Consumer perception on e-service quality: from Internet purchases and non-purchases perspectives", Journal of Business Strategies, Vol. 19, No. 1, pp. 19-41.

Yang, Z.; Peterson, R.T.; Cai, S. (2003). "Service quality dimensions of Internet retailing: an exploratory analysis", The Journal of Services Marketing, Vol. 17, No. 6/7, pp. 685-698.

Yoh, E.; Damhorst, M.L.; Sapp, S.; Laczniak, R. (2003). "Consumer adoption of the Internet: the case of apparel shopping”, Psychology \& Marketing, Vol. 20, No. 12, pp. 1095-1118.

Zeithaml, V.A.; Parasuraman, A.; Malhotra, A. (2002). "Service quality delivery through web sites: a critical review of extant knowledge", Journal of the Academy of Marketing Science, Vol. 30, No. 4, pp. 362375.

Zhao, S.; Grasmuck, S.; Martin, J. (2008). "Identity construction on Facebook: digital empowerment in anchored relationships", Computers in Human Behavior, Vol. 24, No. 5, pp. 1816-1836. 